\title{
HERBIGATION MANAGEMENTS FOR MAXIMIZING GREEN BEANS CROP PRODUCTIVITY UNDER DRIP IRRIGATION SYSTEM
}

Shaimaa B.Y. Elsayed ${ }^{1 \star}$, Abdel-Aziz A.A. ${ }^{1}$, El-Bagoury K.F. ${ }^{1}$ and Moustafa M.M. ${ }^{2}$

1. Agric. Engineering Dept., Fac. of Agric., Ain Shams Univ., P.O. Box 68 Hadyek Shoubra 11241, Cairo, Egypt

2. Agric. Engineering Research Institute, Agriculture Research Center, Giza, Egypt.

*Corresponding author: eng.shaimaabadr@gmail.com

Received 3 February, 2019, Accepted 27 February, 2019

\section{ABSTRACT}

A field experiment was conducted at the Experimental Farm at Faculty of Agriculture, Ain Shams University (loam soil); to study herbigation managements for maximizing green beans crop productivity under drip irrigation system.

Two application techniques were used for weed control with pre-emergence Pendimethalin herbicide (Stomp 50\% EC), the first application technique was injection herbicide through drip irrigation systems (surface and sub-surface) with three concentrations $(100 \%, 75 \%$ and $50 \%)$ of herbicide recommendation dose (1.7 L/ fed) using venture device, secondly by conventional spraying using knapsack sprayer and control without treatment.

The results showed that the best water application efficiency was (96\%) and the highest value of water distribution uniformity was $(95 \%)$ achieved with Sub surface-drip irrigation system. The best weeds control efficiency was (82\%) achieved with injection herbicide through sub surface-drip irrigation system with $75 \%$ - $(1.28 \mathrm{~L} / \mathrm{fed})$ - of the herbicide recommendation dose in compare with other treatments, which maximized the benefit from the applied herbicides and obtained high productivity and an export product with high quality. According to the obtained results herbigation with sub-surface irrigation system is an excellent method of controlling weeds for the growers with good management.

Key Words: Drip irrigation systems, Herbigation, Green Beans, Weed control, Herbicide application techniques, Herbicides injection, Pendimethalin

\section{INTRODUCTION}

Weeds are major production problem in cultivation, especially in the most important elements (water and fertilizer, space, light) and for being the primary host for many diseases and agricultural pests, which affect the overall production, when the supply of any or all of these essentials is not adequate for the optimum growth of the crop and weed, interference or competition occurs. Considerable variation exists among species of crops and weeds in their competitive ability. A weed consider strong plant competitor, retards the growth of other plants growing in association with it. Strong competitors dominate because of faster and taller growth, early emergence and larger embryos.

As the weeds are causing big annual losses in crop yield and quality, combined with the costs of weed control which are the greatest in the world, thus world pesticide expenditures at the producer level totaled nearly $\$ 56$ billion in between 2008 and 2012, expenditures on herbicides consistently accounted for the largest portion of total expenditures in all years Within the agricultural sector (approximately $45 \%$ ), followed by expenditures on insecticides, fungicides, and other pesticides, respectively "U.S. Environmental Protection Agency, 2012". At Egypt weeds cause low economic outcome $20-30 \%$ and it could reach $70-80$ $\%$ in some weak growing crops .

Herbigation, one of the most chemigation used by injecting the herbicides into water of irrigation systems, is a relatively recent development in weed control technology. Research findings have established a fact that some of the herbicides exhibit good activity by providing control of target weeds when applied through irrigation water and 
these agree with Lange et al. (1974) who found good control of grasses around the emitters when triflualin was applied through a trickle irrigation system usually don't move as a far in the soil as the irrigation water, the site of the weed in free area around the emitters is affected primarily by the degree of adsorption of the herbicide by the soil but is also affected by the concentration of the herbicide, the amount of water applied, and the length of the injection period. Also Burt (1999), Ahmed et al (2001) and Abdel-Aziz (2006) mentioned that chemical methods are considered more effective as a simple and quick method of weed control

\section{The aims of the research}

1. Weeds control with maximize the benefit of herbicides through injecting it into the modern pressurized irrigation systems with lower costs.

2. Save water and chemicals to increase the productivity of bean crop yield.

3. Improving the advantage part of using drip irrigation system in herbigation.

\section{MATERIALS AND METHODS}

\section{1- Experimental site and crop}

Field experiments were carried out in the Experimental Farm at Faculty of Agriculture, Ain Shams University.

\section{2- Crop}

Green Beans (Poulista- Phaseolus vulgaris) were planted at the mid of Feb., 2018 after soil preparation (Loam soil) by ploughing using chisel plow adding fertilizer Requirements According to Ministry of Agriculture and Land Reclamation.

\section{3- Soil properties}

Soil samples were taken from different depths of the soil to determine the physical and chemical properties of soil.

\section{4- Water analysis}

Water sample were taken from irrigation water source at faculty of Agriculture, Ain Shams University (Experiment location) to determine the chemical and hydro-physical properties. They are shown in Table (3).

Table 1. Soil chemical properties.

\begin{tabular}{|c|c|c|c|c|c|c|c|c|c|c|c|}
\hline \multirow{2}{*}{$\begin{array}{c}\text { Soil } \\
\text { Sample } \\
\text { Depth } \\
\text { (cm) }\end{array}$} & \multirow[b]{2}{*}{$\mathrm{pH}$} & \multirow[b]{2}{*}{$\begin{array}{c}E C \\
\mathrm{dS} / \mathrm{m}\end{array}$} & \multicolumn{4}{|c|}{ Cations in meq/l } & \multicolumn{4}{|c|}{ Anions meq/l } & \multirow[b]{2}{*}{$\begin{array}{c}\text { SAR } \\
\%\end{array}$} \\
\hline & & & $\mathrm{Ca}^{++}$ & $\mathrm{Mg}^{++}$ & $\mathrm{Na}^{+}$ & $\mathrm{K}^{+}$ & $\mathrm{HCO}_{3}^{-}$ & $\mathrm{CO}_{3}^{-}$ & $\mathrm{Cl}^{-}$ & $\mathrm{SO}_{4}^{-}$ & \\
\hline $0-15$ & 8.7 & 0.5 & 1.5 & 1.5 & 1.71 & 0.63 & 0.4 & 0 & 4 & 1 & \\
\hline $15-30$ & 8.17 & 0.51 & 1.5 & 1.5 & 1.75 & 0.63 & 0.2 & 0 & 4.1 & 1.2 & 8.51 \\
\hline $30-45$ & 8.15 & 0.5 & 1.2 & 2.0 & 1.64 & 0.54 & 0.2 & 0 & 4 & 1 & \\
\hline
\end{tabular}

(pH: the decimal logarithm of the reciprocal of the hydrogen ion activity, EC: Electrical conductivity, SAR: Sodium adsorption ratio)

Table 2. Soil physical properties.

\begin{tabular}{|c|c|c|c|c|c|c|c|}
\hline \multirow{2}{*}{$\begin{array}{c}\text { Sample } \\
\text { depth }\end{array}$} & \multicolumn{2}{|c|}{ Particle Size Distribution, \% } & \multirow{2}{*}{ F.C \% } & W.P\% & $\begin{array}{c}\text { B.D } \\
\mathbf{g} / \mathbf{c m}^{\mathbf{3}}\end{array}$ & $\begin{array}{c}\text { Texture } \\
\text { class }\end{array}$ \\
\cline { 2 - 7 } & Sand & Silt & clay & & & 1.32 & Loam \\
\hline $0-45$ & 32.6 & 45.39 & 22.01 & 32.5 & 21.82 & 1.52 \\
\hline
\end{tabular}

(F.C: Field Capacity, W.P: Wilt Point, B.D: Particle Density) 
Table 3. Chemical properties and hydrophysical of irrigation water.

\begin{tabular}{|c|c|c|c|c|c|c|c|c|c|}
\hline \multirow{2}{*}{$\begin{array}{c}\mathrm{EC} \\
(\mathrm{ds} / \mathrm{m})\end{array}$} & \multirow{2}{*}{$\mathrm{pH}$} & \multicolumn{4}{|c|}{ Cations in meq/I } & \multicolumn{4}{c|}{ Anions meq/l } \\
\cline { 3 - 10 } & & $\mathbf{C a}^{++}$ & $\mathbf{M g}^{++}$ & $\mathbf{N a}^{+}$ & $\mathbf{K}^{+}$ & $\mathbf{H C O}_{3}{ }^{-}$ & $\mathbf{C O}_{3}^{-}$ & $\mathbf{C l}^{-}$ & $\mathbf{S O}_{4}^{--}$ \\
\hline 0.4 & 7.3 & 2.19 & 0.43 & 1.32 & 0.16 & 1.65 & -- & 1.6 & 0.85 \\
\hline
\end{tabular}

(pH: the decimal logarithm of the reciprocal of the hydrogen ion activity, EC: Electrical conductivity)

\section{5- Irrigation system}

Two irrigation systems were used:

- Surface drip irrigation.

- Sub-Surface drip irrigation.

\section{- Irrigation system components Fig (1).}

\section{Injection unit}

\section{a) Venture Injectors Device}

Venture-type chemigation injectors are widely used due to their advantages: they do not require electric power and are cheap to operate. The correct characterization of these systems requires pressures to be correctly set at the inlet and outlet points in relation to main and injected solution flows. These analytical relationships, as described in the International Organization for Standardization's standard ISO 15873:2002. Manzano (2018).

\section{- Venture Characterization:}

$3 / 4$ inch, with flow rate $(45 \mathrm{l} / \mathrm{hr}$.). At pressure (inlet 2.5bar- outlet 2 bar).

\section{- Calibration}

Harrison (1982) stated that calibration of injectors can be accomplished by coordinating the injected volume with the area covered in irrigation during the injection times as follows:

Injected rate $=($ injected volume $/$ area $) \times($ area $/$ injected time)

\section{- Chemigation Requirement calculations for venture}

For pressurized injection system the following equation is used according to:

$$
\mathbf{Q}=\frac{F \times A}{C \times T \times I}
$$

Where:

$Q=$ Injection rate of liquid chemicals $(L / h)$,

$\mathrm{F}=$ chemicals application rate per irrigation cycle $(\mathrm{kg} / \mathrm{ha})$,

$A=$ Irrigation area in specific time (ha),

$\mathrm{C}=$ concentration of the actual chemicals in the solution $(\mathrm{kg} / \mathrm{L})$

$\mathrm{T}=$ Irrigation time $(\mathrm{h})$, and

$\mathrm{I}=$ Ratio between chemicals and irrigation time.

b) Filtration System

- Screen type, $3 / 4$ inch - 120 micron, with charge rate $\left(3-4 \mathrm{~m}^{3} / \mathrm{hr}\right.$.)

c) Main line: a U.P.V.C pipe $50 \mathrm{~mm}$ out diameter, PIN 6 bar to convey the water from the water source to sub- main lines passing by the injection unit.

d) Sub- main line: a U.P.V.C pipe $32 \mathrm{~mm}$ diameter, PIN 6 bar.

e) P.E laterals line: $16 \mathrm{~mm}$ outer, laterals drip built-in (4 L. hr. $/ 30 \mathrm{~cm}$ spacing).

In the sub-surface drip irrigation system, laterals drip lines were buried at $10 \mathrm{~cm}$ depth from soil surface.

\section{6- Irrigation requirement}

Irrigation water requirement for Green Beans (Paulista- Phaseolus vulgaris) was calculated as follows:

a- Crop consumptive use was calculated according to Doorenbos and Pruitt (1977):

$\mathrm{Etc}=\mathrm{Et}_{0} \times \mathrm{Kc}$.

Where:

Etc. $=$ crop consumptive use, $\mathrm{mm} /$ day,

$\mathbf{E t}_{0}=$ reference evapotranspiration, $\mathrm{mm} /$ day .

Kc. $=$ crop coefficient. (Variable 0.5, 1.05, 0.9 depending on the plant growth stage) for Green Beans crop was used according to FAO (1956). 


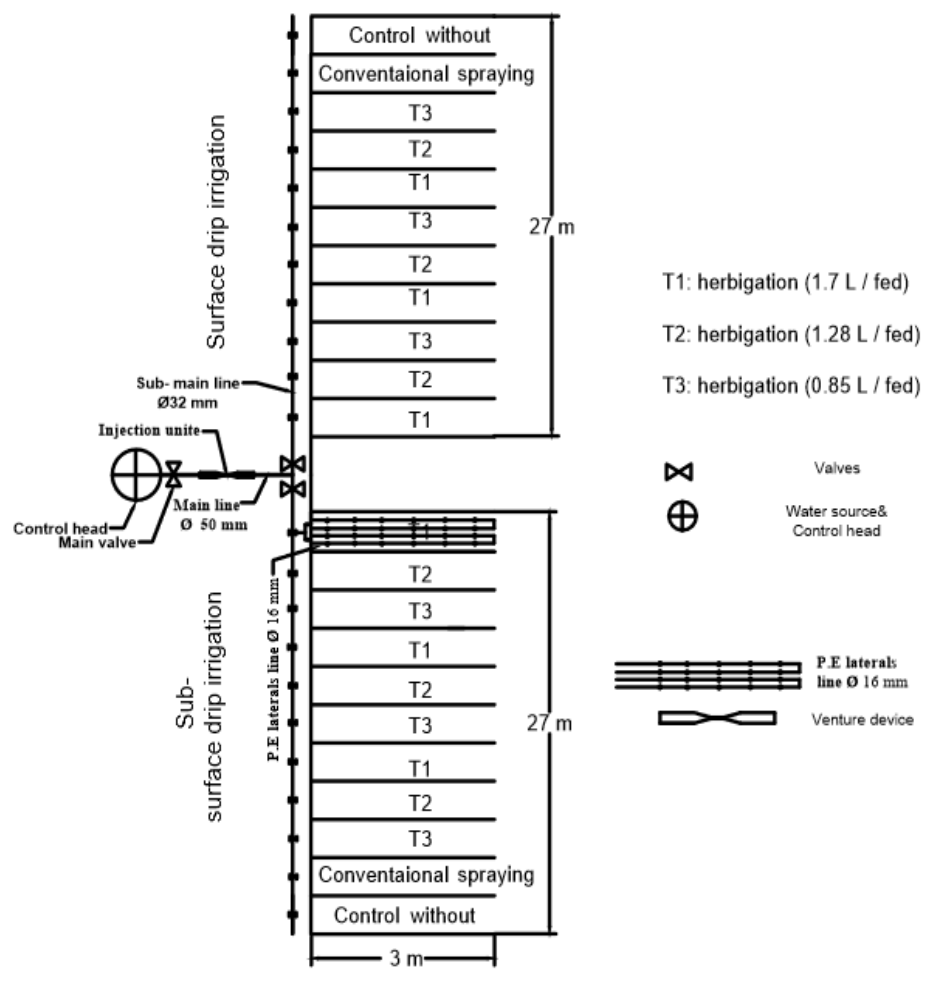

Fig. 1. Experimental layout for Irrigation system components and treatments

b- Applied irrigation water for Green Beans crop was calculated according to Vermeiren and Jobling (1980).

$$
\mathrm{IR}=[\operatorname{Etc}(1+\mathrm{LR}) \times 4.2 / \mathrm{Ea}] \times
$$

\section{Where:}

$\mathrm{IR}=$ applied irrigation requirement, $\mathrm{m}^{3} / \mathrm{fed}$. irrig., $\mathrm{LR}=$ leaching requirement, $\%$ and

$\mathrm{Ea}=$ application efficiency, \% and

$\mathrm{I}=$ irrigation intervals, days

\section{7- Herbicide: Stomp® $80 \%$ EC}

Stomp ${ }^{\circledR} 50 \%$ EC is an orange-yellow liquid Emulsive herbicide of the dinitroaniline type, whose active ingredient is pendimethalin. Stomp contains the inert components (50\%); as petroleum solvents (naphthalene and ethylene dichloride).

Common Name: Pendimethalin

Chemical Name: n-(1-ethylpropyl)-3, 4-dimethyl2,6 dinitrobenzenamine)

Chemical Family: Dinitroaniline

\section{Structural formula}<smiles>CCC(CC)Nc1c([N+](=O)[O-])cc(C)c(C)c1[N+](=O)[O-]</smiles>

Recommendation dose: $1.7 \mathrm{~L} /$ fed.

The pre-harvest interval (PHI): 60 days.

Mode of Action: A microtubule disruptor. (USEPA 1997b).

\section{8- Weed control methods:}

a- Herbigation: Stomp herbicide or (Pendmethline $50 \%$ EC) was applied at three dosage rates, which are 1.7, 1.28 and $0.85 \mathrm{l} / \mathrm{fed}$ represents (100, 75 and $50 \%$ of recommended rate) were applied with irrigation water by using venture device $(3 / 4 \mathrm{inch})$ through drip irrigation systems before cultivation.

b- Conventional spraying Stomp herbicide or (Pendmethline 50\% EC) at an application intensity of $1.7 \mathrm{~L} / \mathrm{fed}$; the herbicide was applied 
on weeds directly using a manual sprayer (A 16 liter volume, single nozzle and hand pump with spraying pressure of 2- 4 bar).

\section{9- Measurements and calculations}

\section{1- Irrigation systems evaluation}

a- Irrigation system efficiency (Ei) was calculated from the following formula according to $\mathrm{Wu}$ and Gtilin, 1975.

$$
\mathrm{Ei}=\mathrm{Ea} \times \mathrm{Eu}
$$

\section{Where:}

$$
\begin{aligned}
& E a=\text { Application efficiency, \% } \\
& E u=\text { Emission Uniformity, \% } \\
& E a=(\text { WDZ / DT }) \times 100
\end{aligned}
$$

Where:

WDZ = Depth of water stored in the root zone, $\mathrm{cm}$

$$
\text { DT }=\text { Gross depth of applied water, cm }
$$

\section{b- Distribution uniformity for trickle irrigation} system was estimated as follows

Water distribution uniformity for trickle irrigation system was determined by selecting 16 emitters from each plot randomly. The flow rate of the emitters was measured. The emission uniformity was calculated according to Keller and Karameli (1975).

$$
E U=1 / 2[(Q n / Q a)+(Q a / Q x)] 100
$$

Where:

EU = field emission uniformity, \%,

$\mathrm{Qn}=$ average of the lowest (1/4) of the emitters flow rate, $\mathrm{l} / \mathrm{h}$,

$\mathrm{Qa}=$ average of the all emitters flow rate, $\mathrm{l} / \mathrm{h}$ and

Qx = average of the highest $(1 / 8)$ of emitters flow rate, $\mathrm{l} / \mathrm{h}$.

c- Emitter manufacture's coefficient of variation:

The manufactures coefficient of variation "CV" indicates to the variation in flow rate for a given emitter. It was calculated by measuring the flow rate from a sample of new emitters after ASAE, 2003 as follows:

$$
\mathrm{CV} \%=\frac{S}{q_{m}} \times 100
$$

Where:

$\mathrm{q}_{\mathrm{m}}=$ Average flow rate $(\mathrm{l} / \mathrm{h})$

$\mathrm{S}=$ Stander deviation of emitter flow rates at a reference pressure head.

\section{2- Total yield productivity}

Yield of green pods were picked manually to calculate the average total green pods yield/plant and strew yield/plant for each plot then weighed in $\mathrm{kg}$. Total yield of green beans and strew was estimated in ( $\mathrm{kg}$ per feddan).

Total yield $/$ fed $=$ Average weight pods $/$ plant $\times$ Number of plant/fed.

\section{3- Quality of fruits}

\section{- Vegetative growth parameters}

A representative sample of 10 plants from each plot was randomly selected to record:

- $\quad$ Plant height $(\mathrm{cm})$.

- $\quad$ Diameter of Plant (mm).

- Number of leaves / plant.

- Area of leaves $\left(\mathrm{cm}^{2}\right)$.

- pod quality parameters

Pods Length $(\mathrm{cm})$.

Pods weight $(\mathrm{g})$.

Pod thickness (mm).

\section{4- Weed control evaluation}

Weeds were collected from randomly selected areas (1m by $1 \mathrm{~m}$ quadrate) within each plot at one and two month after sowing and biomass of weeds weighted to determine the total fresh weight, then calculated weed control efficiency using the formula suggested by Mani et al (1973) and expressed in percentage.

WCE\% =

$$
\frac{\text { weight ofweeds unweeded control-weight of treatment plot }}{\text { weight of weeds unweeded control }} \times 100
$$

\section{0- Experiment layout and design}

The experimental area of $162 \mathrm{~m}^{2}$ was divided into two plots, the design used was split - split plot with three replications and control (without treatment - conventional spraying); the first part was designed for installing surface drip irrigation $81 \mathrm{~m}^{2}$ and it was divided into 10 sub -plots $(3 \times 2.7 \mathrm{~m}$ for each), and the second part was designed for in- 
stalling the sub - surface drip irrigation and it was the same as shown in Fig. (1).

\section{RESULTS AND DISCUSSION}

\section{1- Irrigation system evaluation}

Table (4) showed that the average water application efficiency for both surface and sub-surface drip irrigation system was $96 \%$ increasing for subsurface drip by $4 \%$ more than the application efficiency of surface drip irrigation system (92\%), and the values of water distribution uniformity were $95 \%$ and $94 \%$ for sub-surface and surface drip irrigation systems, respectively. On the other hand, the highest value of total irrigation efficiency was $91 \%$ under sub-surface drip irrigation compared to $86.5 \%$ under surface drip irrigation system. This is may be due to the least percentage of water loss resulting from evaporation and deep percolation under sub- surface drip irrigation system. This compatible with that "the use of sub-surface drip irrigation (SSDI) systems may provide an improvement in irrigation water use efficiency. These systems apply irrigation water directly inside the ground instead of on the surface irrigation" Ayars et al 1999.

Table 4. Evaluation of drip Irrigation systems efficiencies.

\begin{tabular}{|c|c|c|c|}
\hline $\begin{array}{c}\text { Drip Irriga- } \\
\text { tion System }\end{array}$ & $\begin{array}{c}\text { Water ap- } \\
\text { plication } \\
\text { efficiency,\% }\end{array}$ & $\begin{array}{c}\text { Distribution } \\
\text { uniformity,\% }\end{array}$ & $\begin{array}{c}\text { Irrigation } \\
\text { efficiency,\% }\end{array}$ \\
\hline Surface & 92 & 94 & 86.5 \\
\hline Sub-surface & 96 & 95 & 91.2 \\
\hline
\end{tabular}

\section{2- Evaluation of the manufactures coefficient of variation "CV"}

The resulted showed in table indicated to the coefficient of variation for a given emitter was $4.5 \%$ and it was Excellent according to ASAE, 2003.
Table 5. The Emitter manufacture's coefficient of variation $(\mathrm{CV}) \%$

\begin{tabular}{|c|c|c|c|c|c|}
\hline \multirow{2}{*}{ Dripper } & \multicolumn{3}{|c|}{$\begin{array}{c}\text { Flow rate } \\
\text { L/h. }\end{array}$} & $\begin{array}{c}\text { Manufacture coef- } \\
\text { ficient of variation } \\
\text { (cv) \% }\end{array}$ \\
\cline { 2 - 6 } & Nominal & Mean & S.D & CV\% & $\begin{array}{c}\text { ASAE } \\
\text { stander }\end{array}$ \\
\hline $\begin{array}{l}\text { Built in } \\
\text { dripper }\end{array}$ & 4 & 3.97 & 0.18 & 4.5 & Excellent \\
\hline
\end{tabular}

CV: coefficient of variation, S.D: Stander Division

\section{3-Effect of irrigation system}

A- Effect of irrigation system on productivity and pod quality parameters

Data proved that the best productivity (pods and strew) $\mathrm{kg} / \mathrm{fed}$, and quality parameters of pods length $(\mathrm{cm})$, pods weight $(\mathrm{g})$ and pod thickness $(\mathrm{mm})$ were achieved with Sub surface drip irrigation system. There was significant between subsurface and surface drip irrigation system as shown in Table (6).

Table 6. Effect of irrigation system on productivity and pod quality parameters

\begin{tabular}{|c|c|c|c|c|c|}
\hline \multirow{2}{*}{$\begin{array}{c}\text { Variable \& } \\
\text { treatment }\end{array}$} & \multicolumn{2}{|c|}{$\begin{array}{c}\text { Mean Productivity } \\
\text { (kg/fed) }\end{array}$} & \multicolumn{3}{|c|}{ Pod quality parameters } \\
\cline { 2 - 6 } & Pods & Straw & $\begin{array}{c}\text { Pods } \\
\text { length } \\
\text { (cm) }\end{array}$ & $\begin{array}{c}\text { Pods } \\
\text { weight } \\
(\mathbf{g})\end{array}$ & $\begin{array}{c}\text { Pod } \\
\text { thickness } \\
(\mathbf{m m})\end{array}$ \\
\hline SSDI & $6087.2^{\mathbf{A}}$ & $1477.57^{\mathrm{A}}$ & $9.3^{\mathbf{A}}$ & $6.7^{\mathbf{A}}$ & $7.3^{\mathbf{A}}$ \\
SDI & $4817.4^{\mathbf{B}}$ & $1167.20^{\mathbf{B}}$ & $8.9^{\mathbf{B}}$ & $5.9^{\mathbf{B}}$ & $6.9^{\mathbf{A}}$ \\
LSD & 147.62 & 56.949 & 0.19 & 0.123 & 0.213 \\
\hline
\end{tabular}

(SSDI: Sub surface drip irrigation system, SDI: Surface drip irrigation system)

Means with the same letter are not significantly different.

\section{B- Effect of irrigation system on Vegetative growth parameters}

Data showed in Table (7) shows significant increase of plant height $(\mathrm{cm})$, number of leaves /plant and Area of leaves $\left(\mathrm{cm}^{2}\right)$ with sub surface drip irrigation system compared with surface drip irrigation system but there was no significant different between the two types of irrigation systems in plant diameter $(\mathrm{mm})$. 
Table 7. Effect of irrigation system on vegetative growth parameters

\begin{tabular}{|c|c|c|c|c|}
\hline \multirow{2}{*}{$\begin{array}{c}\text { Variable \& } \\
\text { treatment }\end{array}$} & \multicolumn{4}{|c|}{ Mean vegetative growth parameters } \\
\cline { 2 - 5 } & $\begin{array}{c}\text { Plant } \\
\text { height } \\
(\mathrm{cm})\end{array}$ & $\begin{array}{c}\text { Number of } \\
\text { leaves / } \\
\text { plant }\end{array}$ & $\begin{array}{c}\text { Area of } \\
\text { leaves } \\
\left(\mathrm{cm}^{2}\right)\end{array}$ & $\begin{array}{c}\text { Diameter } \\
\text { of Plant } \\
(\mathrm{mm})\end{array}$ \\
\hline S-SD & $34.8^{\mathbf{A}}$ & $4^{\mathbf{A}}$ & $53.8^{\mathbf{A}}$ & $6.8^{\mathbf{A}}$ \\
SD & $33.56^{\mathbf{B}}$ & $39.7^{\mathbf{B}}$ & $49.25^{\mathbf{B}}$ & $6.5^{\mathbf{A}}$ \\
\hline LSD & 078 & 1.597 & 0.907 & 0.75 \\
\hline
\end{tabular}

Means with the same letter are not significantly different.

\section{C- Effect of irrigation system on weed control}

Results showed in Table (8) expresses a significant increase on weed weight under surface drip irrigation system while the lowest weights were obtained by sub- surface drip irrigation system which achieved the highest values of weed control efficiency (82\%).
Table 8. Effect of irrigation system on weed control

\begin{tabular}{|c|c|c|}
\hline \multirow{2}{*}{$\begin{array}{l}\text { Variable \& } \\
\text { treatment }\end{array}$} & \multicolumn{2}{|c|}{$\begin{array}{c}\text { Mean weight of weeds grown } \\
\text { after treatment }\left(\mathrm{g} / \mathrm{m}^{2}\right)\end{array}$} \\
\hline & One month & Two month \\
\hline $\begin{array}{c}\text { SD } \\
\text { S-SD }\end{array}$ & $\begin{array}{l}391.9^{A} \\
241.7^{B}\end{array}$ & $\begin{array}{l}599.9^{A} \\
433.4^{B}\end{array}$ \\
\hline LSD & 7.0 & 36.88 \\
\hline
\end{tabular}

Means with the same letter are not significantly different.

4- Effect of interaction between weed control techniques and herbicide concentration under drip irrigation systems on the following:

\section{A- Productivity and pod quality parameters:}

The data in Fig. (2) showed that the highest productivity of pods yield and straw yield were achieved under sub-surface drip irrigation with (7.8) and (2.1) ton/fed, respectively followed by surface drip irrigation under the same concentration $(100 \%$ of the recommendation). Statistical analysis showed a significant different between application techniques. This is due to the high efficiency of the sub-surface irrigation system in inhibiting the growth of weeds in the critical period of the plant life, which lead to increased productivity of this system

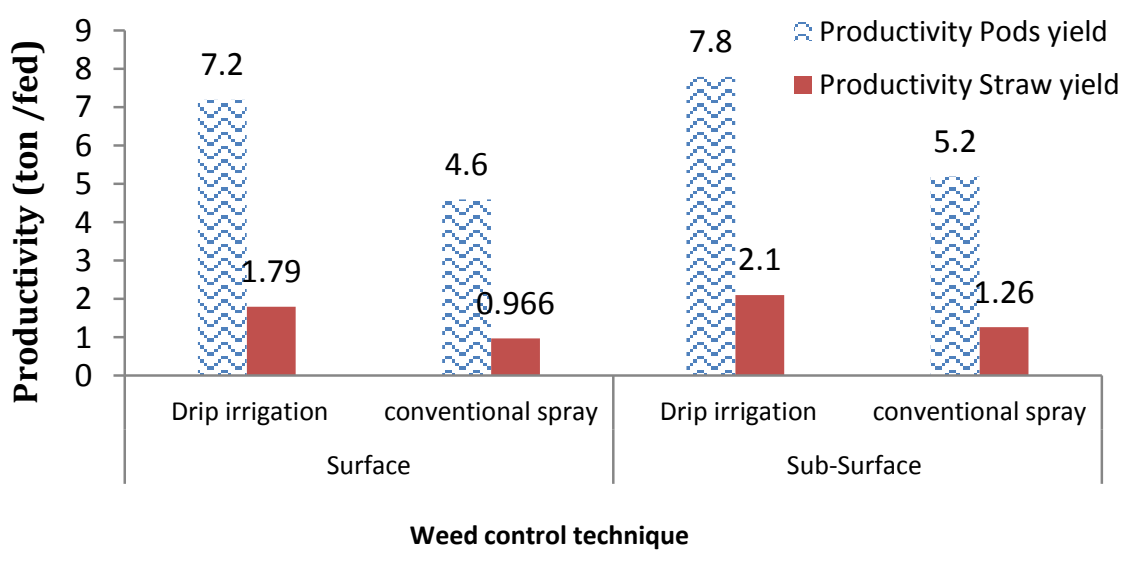

Fig. 2. Effect of weed control technique on green beans pods yield.

B- Effect of different herbicide concentrates injected through drip irrigation system on green beans pods yield and straw

The data in Figs. (3 and 4) showed that the highest productivity for pods and straw yield (ton/fed) were achieved under sub-surface drip irrigation with $100 \%$ of dosage rate $(1.7 \mathrm{l} \mathrm{l} / \mathrm{fed})$, followed $75 \%$ (of dosage rate $(1.28 \mathrm{l} / \mathrm{fed}$ ) where the mean difference between them was not significant for pods yield as shown in Table (9). 


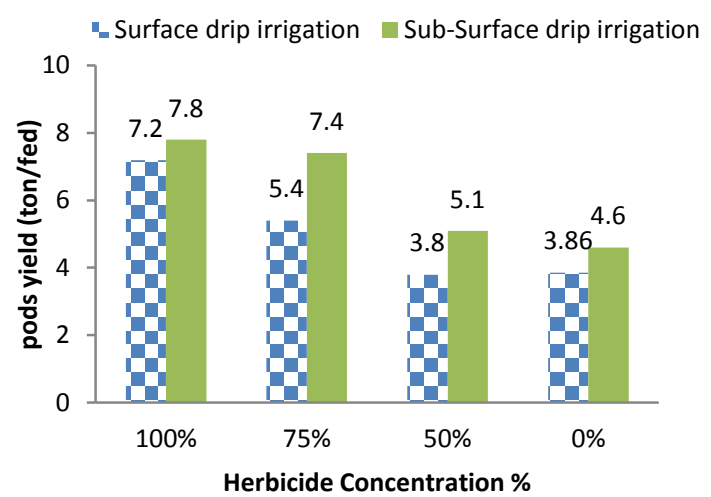

Fig. 3. Effect of herbicide concentrates on green beans yield

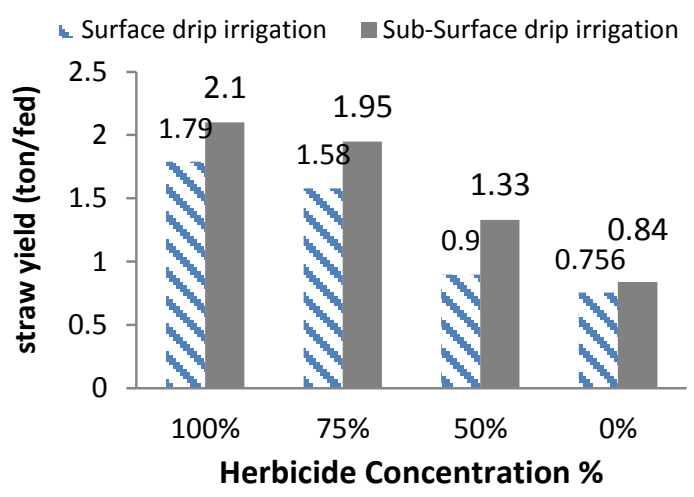

Fig. 4. Effect of herbicide concentrates on straw yield

Table 9. Effect of different herbicide concentrates injected through drip irrigation system on green beans pods yield and straw

\begin{tabular}{|c|c|c|c|c|c|c|c|}
\hline Variable \& & \multirow{2}{*}{\begin{tabular}{c}
\multirow{2}{*}{ treatment } \\
Productivity
\end{tabular}} & \multicolumn{2}{|l|}{ Herbicide concentration,\% } & Spraying & \multirow{2}{*}{ LSD } \\
\cline { 3 - 7 } & & $0 \%$ & $50 \%$ & $75 \%$ & $100 \%$ & $100 \%$ & \\
\hline S-SD & Pod & $4620^{\mathrm{E}}$ & $5614^{\mathrm{C}}$ & $7343^{\mathrm{A}}$ & $7609^{\mathrm{A}}$ & $5250^{\mathrm{D}}$ & \multirow{2}{*}{330.1} \\
SD & (kg/fed) & $3780^{\mathrm{F}}$ & 3549 & $5201^{\mathrm{D}}$ & $6937^{\mathrm{B}}$ & $4620^{\mathrm{E}}$ & \\
\hline S-SD & Straw & $840^{\mathrm{FG}}$ & $1300^{\mathrm{E}}$ & $1914^{\mathrm{B}}$ & $2073^{\mathrm{A}}$ & $1260^{\mathrm{E}}$ & \multirow{2}{*}{127.4} \\
SD & $(\mathbf{k g} / \mathbf{f e d})$ & $756^{\mathrm{FG}}$ & $878^{\mathrm{FG}}$ & $1552^{\mathrm{D}}$ & $1683^{\mathrm{C}}$ & $966^{\mathrm{F}}$ & \\
\hline
\end{tabular}

Means with the same letter are not significantly different.

\section{B- Pods quality parameters}

Statistical analysis showed that the perfect quality parameters of pods length $(\mathrm{cm})$, pods weight $(\mathrm{g})$ and pod thickness $(\mathrm{mm})$ were achieved with $(100 \%)$ of dosage rate $(1.7 \mathrm{l} / \mathrm{fed})$ of herbicide followed by $(75 \%)$ of dosage rate $(1.28 \mathrm{l} / \mathrm{fed})$ under sub-surface drip irrigation system compared with surface drip irrigation system and spraying technique. Mean difference among them was significant as shown in Table (10).

Table 10. Effect of interaction between weed control technique and herbicide concentrates on pods quality:

\begin{tabular}{|c|c|c|c|c|c|c|c|}
\hline \multirow{2}{*}{$\begin{array}{l}\text { Variable \& } \\
\text { treatment }\end{array}$} & \multirow{2}{*}{ Pods quality } & \multicolumn{4}{|c|}{ Herbicide concentration, \% } & \multirow{2}{*}{$\begin{array}{c}\text { Spraying } \\
100 \%\end{array}$} & \multirow{2}{*}{ LSD } \\
\hline & & $0 \%$ & $50 \%$ & $75 \%$ & $100 \%$ & & \\
\hline S-SD & Pods Length & $8.0^{\mathrm{E}}$ & $8.8^{\mathrm{D}}$ & $10.16^{\mathrm{B}}$ & $10.6^{\mathrm{A}}$ & $9.0^{\mathrm{D}}$ & \\
\hline SD & $(\mathrm{cm})$ & $8.0^{\mathrm{E}}$ & $8.1^{\mathrm{E}}$ & $9.5^{\mathrm{C}}$ & $9.8^{\mathrm{BC}}$ & $9.0^{\mathrm{D}}$ & 0.42 \\
\hline S-SD & Pods weiaht & $6.0^{\mathrm{D}}$ & $6.0^{\mathrm{D}}$ & $7.1^{\mathrm{B}}$ & $7.5^{\mathrm{A}}$ & $7.0^{\mathrm{B}}$ & \\
\hline SD & (g) & $5.0^{\mathrm{F}}$ & $5.5^{\mathrm{E}}$ & $6.5^{\mathrm{C}}$ & $6.58^{C}$ & $6.0^{\mathrm{D}}$ & 0.27 \\
\hline S-SD & Pod thickness & $6.0^{\mathrm{F}}$ & $6.5^{\mathrm{E}}$ & $8.1^{\mathrm{B}}$ & $8.83^{A}$ & $6.0^{\mathrm{D}}$ & \\
\hline SD & $(\mathrm{mm})$ & $6.0^{\mathrm{F}}$ & $6.16^{\mathrm{EF}}$ & $7.5^{\mathrm{C}}$ & $8.1^{B}$ & $7.0^{\mathrm{D}}$ & .47 \\
\hline
\end{tabular}

Means with the same letter are not significantly different. 


\section{c- Vegetative growth parameters}

Data at Table (11) showed the impact of usage different concentration through injection with water irrigation and spraying techniques, the best growth parameters were achieved with $(100 \%)$ of herbicide's concentration under sub surface irrigation system followed by $(75 \%)$ for plant height $(\mathrm{cm})$. And Vegetative growth increased significantly with $(75 \%)$ in terms of area of leaves, diameter of plant, number of leaves/plant. This agreed with (Rankova et al 2009) who studied the efficiency of the soil systemic selective herbicide Pendimethalin (Stomp $33 \mathrm{EC})$. According to the obtained results, "Herbigation could be considered an efficient and ecologically sound approach for weed control in modern fruit production. There was no negative effect on both the vegetative growth and yielding and the soil microbial activity and successfully used for herbicide application".

Table 11. Effect of interaction weed control techniques and herbicide concentrates on vegetative growth parameter

\begin{tabular}{|c|c|c|c|c|c|c|l|}
\hline Variable \& & Vegetative & \multicolumn{3}{|l|}{ Herbicide concentration, \% } & \multicolumn{2}{l|}{ Spraying } & \multirow{2}{*}{ LSD } \\
\cline { 3 - 7 } treatment & growth & $0 \%$ & $50 \%$ & $75 \%$ & $100 \%$ & $100 \%$ & \\
\hline S-SD & Plant height & $31.0^{\mathrm{E}}$ & $32.1^{\mathrm{ED}}$ & $37.8^{\mathrm{B}}$ & $39.6^{\mathrm{A}}$ & $34.3^{\mathrm{C}}$ & \multirow{2}{*}{1.75} \\
SD & $(\mathrm{cm})$ & $30.0^{\mathrm{E}}$ & $32.0^{\mathrm{ED}}$ & $33.5^{\mathrm{CD}}$ & $37.0^{\mathrm{B}}$ & $34.0^{\mathrm{C}}$ & \\
\hline S-SD & Number of & $35.0^{\mathrm{D}}$ & $42.6^{\mathrm{C}}$ & $53.1^{\mathrm{A}}$ & $54.8^{\mathrm{A}}$ & $40.1^{\mathrm{C}}$ & \multirow{2}{*}{3.57} \\
SD & leaves / plant & $33.0^{\mathrm{D}}$ & $35.5^{\mathrm{D}}$ & $43.0^{\mathrm{C}}$ & $47.3^{\mathrm{B}}$ & $40.0^{\mathrm{C}}$ & \\
\hline S-SD & Area of leaves & $43.2^{\mathrm{G}}$ & $46.0^{\mathrm{F}}$ & $66.6^{\mathrm{A}}$ & $64.3^{\mathrm{B}}$ & $50.0^{\mathrm{E}}$ & \multirow{2}{*}{2.0} \\
SD & $\left(\mathrm{cm}^{2}\right)$ & $42.1^{\mathrm{G}}$ & $45.5^{\mathrm{F}}$ & $53.6^{\mathrm{D}}$ & $56.8^{\mathrm{C}}$ & $47.0^{\mathrm{F}}$ & \\
\hline S-SD & Diameter of & $5.1^{\mathrm{C}}$ & $6.1^{\mathrm{BC}}$ & $7.8^{\mathrm{A}}$ & $7.3^{\mathrm{AB}}$ & $7.0^{\mathrm{AB}}$ & \multirow{2}{*}{1.69} \\
SD & Plant (mm) & $5.0^{\mathrm{C}}$ & $6.0^{\mathrm{BC}}$ & $7.6^{\mathrm{AB}}$ & $7.1^{\mathrm{AB}}$ & $7.0^{\mathrm{AB}}$ & \\
\hline
\end{tabular}

Means with the same letter are not significantly different.

C-Effect of interaction weed control techniques and herbicide concentration under drip irrigation systems on weeds control efficiency

The weed spread in the experimental field was showed the effect of the weed control technique (injection- conventional spraying) with $100 \%$ of dosage rate $(1.7 \mathrm{l} \mathrm{l} / \mathrm{fed})$ of herbicides under drip irrigation systems (surface and subsurface) on percentage of weed control efficiency as shown in Fig. (6). The results show that the highest values of weed control efficiency (82\%) with herbigation under sub- surface irrigation system and the lowest values of weed control efficiency with conventional spraying $(25 \%)$, The results was obtained after the hoe weeding was calculated biomass of weeds was weighted to determine the total fresh weight, then calculated weed control efficiency. This agreed with (Ogg, 1986) the reduced eradication of weeds through sprayer application may be due to dilution of herbicide. In addition, wind distorts the water application pattern, causing the herbicide to the distributed unevenly; high evaporation increases the loss of herbicide.

\section{5- Effect of herbicide concentration on weeds control efficiency:}

The data in Table (12) showed that the lowest of weight of weeds after one and two month of treatment was achieved under sub-surface drip irrigation when the herbicide injected $100 \%$ of dosage rate $(1.71 \mathrm{l} / \mathrm{fed})$, followed by $75 \%$ of dosage rate $(1.28 \mathrm{l} / \mathrm{fed})$ under the same system, and the mean difference between them was not significant. 
Table 12. Effect of interaction between weed control technique and herbicide concentrates on weight of weeds.

\begin{tabular}{|c|c|c|c|c|c|c|c|}
\hline \multirow{2}{*}{$\begin{array}{l}\text { Variable \& } \\
\text { treatment }\end{array}$} & \multirow{2}{*}{$\begin{array}{l}\text { weight of } \\
\text { weeds }\end{array}$} & \multicolumn{4}{|c|}{ Herbicide concentration $\%$} & \multirow{2}{*}{$\begin{array}{c}\text { Spraying } \\
100 \%\end{array}$} & \multirow{2}{*}{ LSD } \\
\hline & & $0 \%$ & $50 \%$ & $75 \%$ & $100 \%$ & & \\
\hline $\begin{array}{c}\text { S-SD } \\
\text { SD }\end{array}$ & One month & $\begin{array}{l}500.0^{\mathrm{B}} \\
700.0^{\mathrm{A}}\end{array}$ & $\begin{array}{c}199^{\mathrm{E}} \\
407.8^{\mathrm{C}}\end{array}$ & $\begin{array}{l}135^{G} \\
179^{F}\end{array}$ & $\begin{array}{c}132^{\mathrm{G}} \\
172.5^{\mathrm{F}}\end{array}$ & $\begin{array}{c}242^{\mathrm{D}} \\
500.0^{\mathrm{B}}\end{array}$ & 15.67 \\
\hline $\begin{array}{c}\text { S-SD } \\
\text { SD }\end{array}$ & Tow month & $\begin{array}{c}900^{\mathrm{B}} \\
1000^{\mathrm{A}}\end{array}$ & $\begin{array}{l}671^{\mathrm{DC}} \\
613^{\mathrm{D}}\end{array}$ & $\begin{array}{c}180.8^{\mathrm{GH}} \\
371^{\mathrm{E}}\end{array}$ & $\begin{array}{l}164.6^{\mathrm{H}} \\
280.3^{\mathrm{F}}\end{array}$ & $\begin{array}{l}250^{\mathrm{GF}} \\
735^{\mathrm{C}}\end{array}$ & 82.47 \\
\hline
\end{tabular}

Mans with the same letter are not significantly different.

\section{SUMMARY AND CONCOLUSION}

Herbigation is an efficient process of applying an agricultural herbicides to the soil or plant surface with an irrigation system by injecting the herbicide into the irrigation water, Depending on the type of irrigation systems.

- Herbicides can be applied by injecting them into an irrigation system or conventional spraying technique

\section{Advantages and benefits of herbigation.}

Harrison and skinner (1981) and Threadgill (1981) discussed the crop production management advantages can be summarized as follows:

- Provides uniform distribution of chemicals which injected with water.

- Offers more flexibility in timing the herbicides application, especially when the field is too wet for a tractor or an aircraft is unavailable or too large spaces which don't allow hoe weeding. Increase herbicides activity and effectiveness for some compounds. Reduce the application cost in some situations. Reduce mechanical damage to plants caused by ground sprayer wheels or conventional spraying technique or hoe weeding. Reduce the risk of soil compaction caused by ground application methods.

\section{The experiment was as follows}

A field experiment was conducted at the Experimental Farm of the Faculty of Agriculture, Ain Shams University (loam soil), to study herbigation managements for maximizing beans crop productivity under drip irrigation system. Two application techniques were used for weed control (injection and Conventional spraying). Preemergence Pendimethalin herbicide (Stomp 50\% EC) was applied through drip irrigation systems (surface and sub-surface) and Conventional spraying by using knapsack sprayer with three concentration $(100 \%, 75 \%$ and $50 \%)$ of the recommendation $(1.7 \mathrm{l} / \mathrm{fed})$ and control without treatment. Results could be concluded as follows:

1. The average of water application efficiency for sub-drip irrigation system was $96 \%$ increasing by $4 \%$ more than the water application efficiency of surface drip irrigation system (92\%) and the values of water distribution uniformity were $95 \%$ and $94 \%$ for sub-surface and surface drip irrigation systems, respectively.

2. The highest productivity was achieved under sub-surface drip irrigation with $100 \%$ of dosage rate $(1.7 \mathrm{l} / \mathrm{fed})$, followed $75 \%$ of dosage rate $(1.28 \mathrm{l} / \mathrm{fed})$ and the mean difference between them was not significant.

3- The best effective control of weeds was subsurface drip irrigation when compared to surface- drip irrigation and conventional spraying using knapsack sprayer.

4. The best concentration of the herbicide is $75 \%$ of dosage rate because there was not significant difference between $100 \%$.

\section{The conclusion}

1- The sub-surface drip irrigation system was able to maximize the effectiveness of herbicides injected through it with irrigation water.

2- Injected herbicides through sub-surface drip irrigation with $75 \%$ of dosage rate increased productivity, pods quality and vegetative growth parameters. 


\section{REFERENCES}

Abdel-Aziz, A.A. 2006. The Use of Chemigation Technique for Weed Vontrol and Minimizing Environmental Pollution with Herbicides in Newly Cultivated Lands. Misr J. Ag. Eng., 23(3), 571- 592.

Ahmed, S.A., El-Suoud, M.R.A. and Metwally, G.M. 2001. Effect of plant density and some weed control treatments on tomato and its associated weeds. Bulletin of the National Research Centre, Cairo, 26 (4), 493-510.

ASAE, 2003. Design and Installation of Micro irrigation System. Engineering Practice ASAE EP409, Agricultural Engineering Year Book of Standards, ASAE, St. Joseph, MI pp. 549550.

Ayars, J.E., Phene, C.J., Hutmocher, R.B., Davis, K.R., Schoneman, R.A., Vail, S.S. and Mead, R. M. 1999. Subsurface drip irrigation of row crops: A review of 15 years of research at the water management research laboratory. Agric. Water Managment, 42 (1), 1-27.

Burt, C.M. 1999. Chemigation: The Irrigation Association. Fairfax, Virginia, USA, pp. 97-102

Doorenbos, J. and Pruitt, W.O. 1977. Guidelines for predicting crop water requirements, FAO Irrigation and Drainage, Paper 24. Rome, Italy. $156 \mathrm{p}$.

FAO, 1956. Guidelines for predicting crop water requirements. FAO Irrigation and Drainage, Rome, Italy. $111 \mathrm{p}$.

Harrison, K.A., Skinner, R.E., 1981, Why use chemigation? proceeding of the National Symposium on chemigation, University of Georgia, GA, USA, pp. 109-112

Harrison, D.S., 1982, Selection, operation, calibration and maintenance of chemigation equipment, proceeding of the Second National Symposium on chemigation, University of Georgia, GA, pp. 74-79.

Keller, J. and Karmeli, D. 1975. Trickle irrigation design. Rain Bird Sprinkler Manufacturing Co. Glendora Calif., 91740 USA, pp. 24-26.
Manzano, J., Palau C.V., Azevedo, B.M., Bomfim, G.V. and Vasconcelos, D. Vi. 2018. Characterization and selection method of Venturi injectors for pressurized irrigation Revista Ciência Agronômica, 49(2) 201-210.

Mani, V.S., Malla, M.L., Gautam, K.C. and Bhagwndas. 1973, Weed killing chemicals in potato cultivation, Indian Farm., 1, 7-18.

MOODY, K. 1993. Weed control in wet-seeded rice. Experimental Agriculture, 29, 393-403.

Ogg, A.G. 1986. Applying herbicides in irrigation water. A review crop protection, 1, 53-65.

Lange, A., Aljibury F., Fischer B., Humphrey, W. and Otto, H., 1974, Weed control under drip irrigation in orchard and vineyard crops, In: Proceeding of the Second International Drip Irrigation Congress, Soil Science \& Ag. Engineering Dept., University of California, Riverside, CA, USA, pp. 422- 424.

Rankova, Z., Koumanov, K.S., Kolev K. and Shilev, S. 2009. Herbigation in a cherry orchard - efficiency of pendimethalin. J. Article, Conference paper Acta Horticulturae. 825(8), 459-464.

Threadgill, E.D., 1981, Why use chemigation? Proceeding of the National Symposium on chemigation, University of Georgia, Tifton, GA, USA, pp. 1-6.

U.S. Environmental Protection Agency, 2012. Pesticides Industry Sales and Usage 20082012 Estimates. Agriculture Market Research Proprietary Date (2005-2012). P.Biological and Economic Analysis Division, Office of Pesticide Programs, Washington, DC20460, pp. 6 -7.

Vermeiren, I. and Jobling, A. 1980. Localized irrigation. Design installation, operation and evaluation. FAO Irrigation and Drainage. Paper No.36, Rome, Italy, 203p.

Wu, I.P. and Gitlin, H.M. 1975 Irrigation efficiencies of surface, sprinkler and drip irrigation. Proceeding Second World Congress International Water Resources Association, New Delhi, (1), 191-199. 



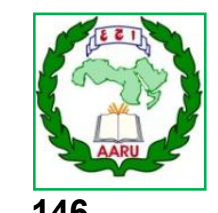

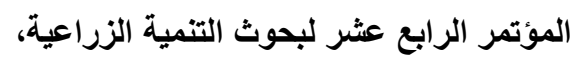

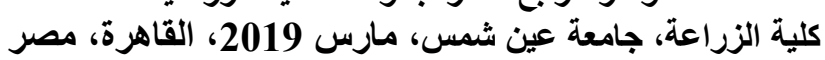

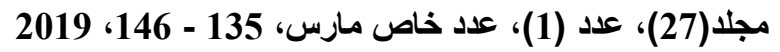

Website: http://strategy-plan.asu.edu.eg/AUJASCI/

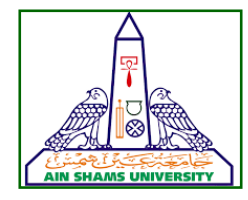

إدراة عملية مكافحة الحشائش لتعظيم إنتاجية محصول الفاصوليا الخضراء

\section{تحت نظام الري بالتثقيط}

[13]

شيماء بلدر يحيى السيد 1- أحمد أبو الحسن عبد العزيز 1- خالد فران الباجوري 1- مصطفي محمود مصطقى2 2

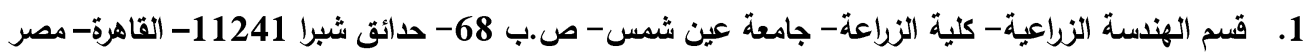

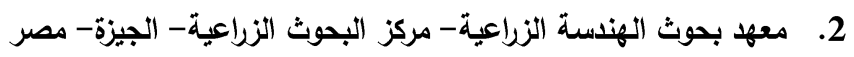

"Corresponding author: eng.shaimaabadr@gmail.com

Received 3 February, 2019, $\quad$ Accepted 27 February, 2019

عليها الآتي: تحقيق أعلى كفاءة لإستخدام المياه في

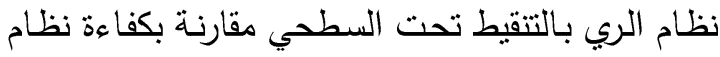
الري بالتتقيط السطحي ، وكذلك كفاءة التوزيع الحقلية.

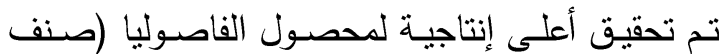

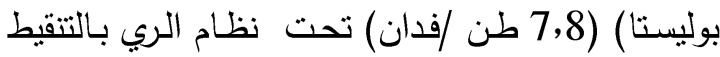

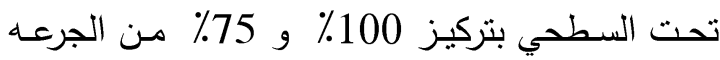

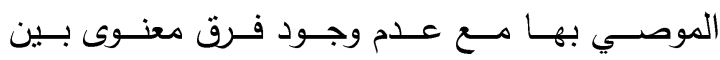

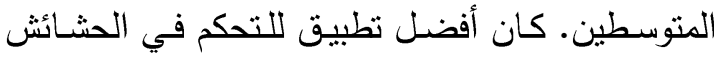

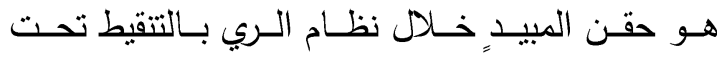

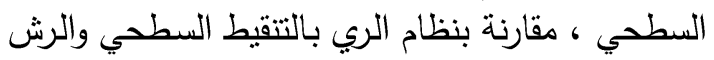

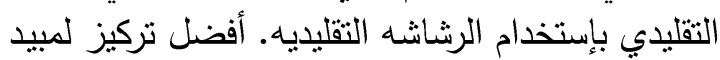

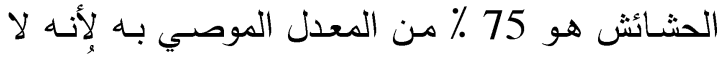

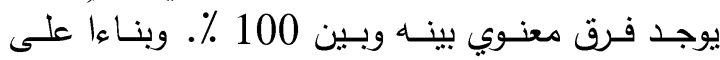

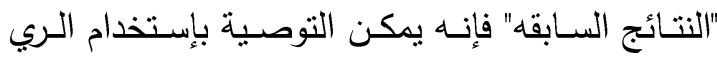

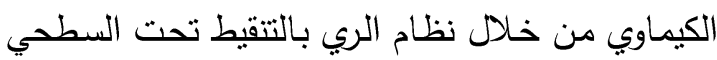

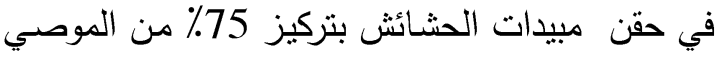
به لزيادة الإنتاجية و تعظيم الإستفاده من المبيد. الكلمات الداله: الري بالتتقيط، الري الكيماوي،

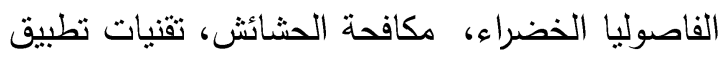

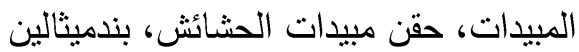

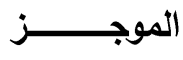

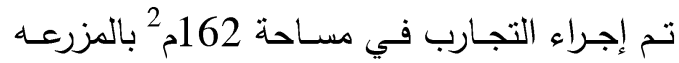

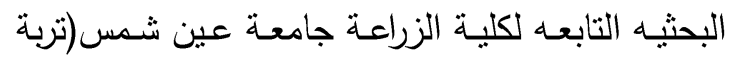

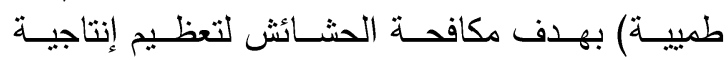
محصول الفاصوليا الخضراء تحت نظام الري بالتنقيط

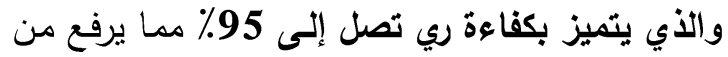
زيـادة تيسير إمتصـاص المبيـدات في منطقـة إنتشــار

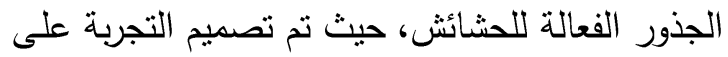

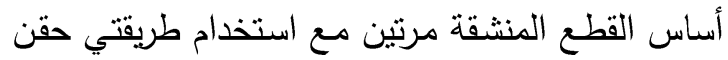

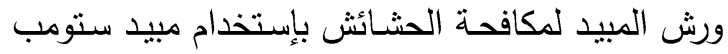

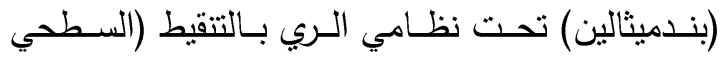

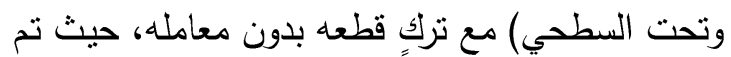

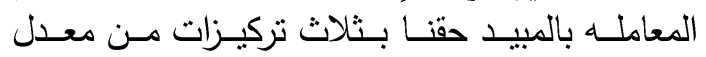

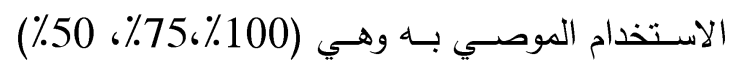

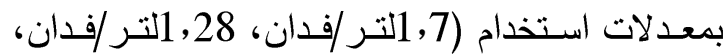

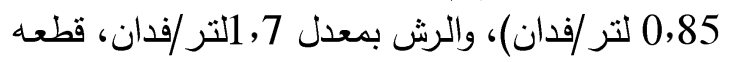

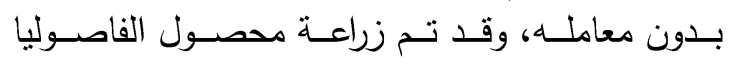

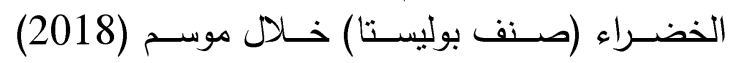

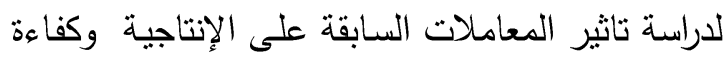

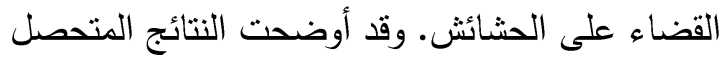

